\title{
The Impact of Climate Change on African Traditional Religious Practices
}

\author{
FABIAN NNANDI U. (PhD) \\ Department of Religion and Cultural Studies, University of Nigeria, Nsukka \\ NCHE GEORGE CHRISTIAN \\ Department of Religion and Cultural Studies, University of Nigeria, Nsukka
}

\begin{abstract}
Developing countries especially in the African continent are bearing the brunt of the impact of climate change. However, what have not been brought to the fore are the impacts of the phenomenon of climate change on African traditional religious practices. This paper, therefore attempts to critically evaluate the impact of climate change on African traditional religious practices. This study is based on two basic assumptions-first, the African traditional religion employs natural elements as mode of expression of its faith. Secondly, the African world is suffused with religion. Using a critical phenomenological method of analysis, it was found that African traditional religion has directly and indirectly been affected by the consequences of climate change in Africa. The paper, however, recommended among other things, a collective cum community adjustment approach to the realities of climate change.
\end{abstract}

Keywords: Climate change, Impact, Nature spirits, African Traditional Religious Practices, Rainmaking, African Continent.

\section{Introduction}

With the indiscriminate melting of the glaciers, the devastating and chronic deluge in several countries, the rise in sea level, the gradual annihilation of some plants and animal species and the evidence of extreme weather conditions around the globe, the reality of climate change has become undisputable. Climate change is the significant increase in the earth's temperature over a long period of time. Mclean and McMillan (2009) have described climate change as;

...a phenomenon whereby solar radiation that has reflected back off the surface of the earth remains trapped at atmospheric levels due to the build-up of carbon dioxide and other green house gases rather than being emitted back into space. The effect of this is the warming of the global atmosphere. It is a long-standing phenomenon as the mix up of the various gases that make up the earth's atmosphere has changed over long periods of time so, average global temperature have fluctuated.

This is largely caused by human activities (anthropogenic factors) through the "combustion of fossil fuels for industrial or domestic usages...biomass burning (resulting in) the production of green house gases and aerosols which have affected the composition of the atmosphere (Umezurike 2012:412). And the consequences are currently affecting all and sundry as climate change is a global phenomenon. Although, it is a global phenomenon with impacts spread across board, these impacts are more deeply felt in developing countries, especially those in the continent of Africa. The consequences of climate change have caused the rise in poverty level, drought, flood and famine, with developing countries bearing the brunt of these effects. For instance, there have been cases of droughts in the Horn of Africa, Southern Africa and Sahel (Christensen et al 2007). In fact, the phenomenon of climate change has affected the socio-economic, health and political life of Africans in a substantial manner.

More interestingly, however, the consequences of climate change have not only affected the social, economic and political aspects of life in Africa, it has also impacted on the traditional religious practices in the continent. It has distorted the weather which was traditionally predictable, affected the patterns of farming and cultivation, and altered the seasons of rituals and festivities. The idea is that African traditional religion finds expression in nature, which goes to establish that anything that affects nature affects the religion, and anything that distorts the natural course of events, affects the traditional religious practices of Africans.

The objective of this paper therefore, is to critically evaluate the impacts of climate change on the African Religious Practices in the continent. Although the focus is on Africa, relevant examples would be drawn from one or two countries in the continent, for emphasis. A Critical Phenomenological method of research will be employed to achieve this objective.

\section{African Traditional Religion}

African traditional religion is the indigenous religion of Africans whose origin is lost in antiquity. However, it is believed to have been practised by African fore-bears who handed it down from one generation to another. Awolalu (1976: 257) has described this religion as; 
...the indigenous religion of the Africans. It is the religion that has been handed down from generation to generation by the fore bearers of the present generation of Africans. It is not a fossil religion (a thing of the past) but a religion that Africans today have made theirs by living it and practicing it.

It is a religion founded on African soil, and inextricably interwoven with the culture of the people, expressed in beliefs and practices, myths and folktales, songs and dances, liturgies, rituals, proverbs, pithy sayings and names, "sacred spaces and objects; a religion which is slowly but constantly updated by each generation in the light of new experiences through the dialectical process of continuities and discontinuities" (Ekwunife 1990:1). It refers to the Africans' belief in the supernatural being(s) (God and spirits) which affects all aspects of their daily lives, "from what they eat (or cannot eat), the way they farm, do everyday chores, hunt, make tools and clothes, arrange themselves in families, marry, divide work among family members, educate their children, treat illness, and bury the dead" (www.exploringafrica.matirx.msu.edu). According to Baum (1999), African traditional religion, like most religious systems, "focuses on the eternal questions of what it means to be human. What is the meaning of life, and what spiritual powers are, and with the natural world and it seeks to portray the world as operating with some degree of order and predictability". A distinguishing characteristic of African traditional religion is the belief in ancestral spirits. African families believe that the "dead are never gone" (Ezechi, 2011:iii). They believe that people continue to live through their spirits, after death. Theses spirits are often referred to as ancestral spirits. It is believed that spirits of the ancestors remain very interested in what happens in their families and communities. Hence, they provide protection against misfortune, drought, disaster, and disease, heal illness, and provide children, protection for livestock, rain and fertility of crops.

\section{Nature in African Traditional Religion}

African traditional religion finds expression in nature. In fact, the relationship between the religion and nature can qualify it to be categorized under the umbrella of "Nature Religion" which according to Beyer (1998) is a "useful analytical abstraction referring to any religious belief or practice in which devotees consider nature to be the embodiment of divinity, sacredness, transcendence, spiritual power or whatever cognate term one wishes to use". For instance, African traditional religion involves the belief in nature spirits. Nature spirits are spirits that inhabit or live in nature. While some African religions teach that there are spirits that live in the skies that control the rain that is so important to the raising of crops and animals, others hold that spirits live in and control rivers, lakes, and oceans. Yet, some religious traditions believe that important ancestral spirits inhabit rocks, mountains and trees.

Also, there is a place for 'totems' which are special animals or any symbolic object that is surrounded with taboos. Totems "serve as emblem of a group of people, such as family, clan, group, lineage or tribe, reminding them of their ancestry (or mystic past)" (Merriam Webster Online Dictionary). These animals that serve as totems are often chosen based on some mythical heroic acts relating to the origin, survival or growth of a group. Hence, some of these totemic animals like snakes, tortoises, agama lizards etc are neither killed nor eaten by the owners, except on rare national occasions/events.

Furthermore, sacred persons like diviners and herbalists have special places in African traditional religion. These persons render some spiritual services to the community, through special medicines and communication with the ancestral spirits. They demystify the causes as well as predict misfortunes, fortunes and illnesses or diseases (in the case of diviners) and provide cure or remedy (in the case of herbalists). For instance, the primary and indispensable thing the herbalist works or cures with are plants, roots and herbs which are provided by nature. Again, the art of rainmaking is also an integral part of African traditional religion. Africans believe that rain is a blessing from the gods which is important for the fertility of crops as well as the health and wealth of man. Yet, there are special persons called rain makers who are believed to possess the power to control or manipulate the natural course of rain. They are responsible for "bringing rain, preventing rain and finding out the cause of a drought and devising a remedy" (www.exploringafrica.msu.edu). Indeed, it should be noted that nature is indispensable in African religious practices. The religion is like a skeleton which finds flesh and body in nature. Is it to talk about more examples like the shrines that are always built with the aid of rocks, caves and trees in forests, the several rituals that celebrate and commemorate special events like planting and harvesting seasons or the earth goddess called "ala" among the Igbo people of the eastern Nigeria which is believed to be the god of fertility and justice?

All these, therefore, go to establish that anything that affects nature affects the religion and anything that distorts the natural course of events affects the religious practice in Africa.

\section{Impact of Climate Change in Africa}

Africa is one of the most vulnerable continents to climate change. The social, economic, domestic and political lives of the people have all received a blow from the phenomenon of climate change. This is made worse by the fact that the continent has an obviously low adaptive capacity. Indeed, the impacts of climate change in Africa are enormous. These impacts range from "decreases in grain yields, changes in runoff and water availability in 
the Mediterranean and southern countries of Africa, to increased stresses resulting from increased droughts and floods; and significant plant and animal species extinctions and associated livelihood impacts" (Boko et al, 2007).

The climate exerts a significant control on the day-to-day economic development of Africa, particularly for the agricultural and water resources sector, at regional, local and household scales. Hence, due to the changes in rain patterns and the availability of water, countries like Kenya, Ethiopia, Tanzania and others have experienced great developmental setbacks. According to the Fourth Assessment Report of the Intergovernmental Panel on Climate change, "about 25\% (about 200million people) of the contemporary African population experiences high water stress and the population at risk of increased water stress in Africa is projected to be between 75-250million and 350-600million people by the 2020s and 2050s respectively" (Boko, et al, 2007). Also, events like droughts and floods have had major implications on several countries in Africa. For instance, droughts have affected the Horn of Africa, Southern Africa and Sahel (Christensen et al 2007). And according to World Water Forum, "one-third of the people in Africa lives in drought-prone areas and is vulnerable to the impacts of droughts (WWF 2000)". Also, floods and deluge have wrecked several African countries like Nigeria, Algeria, Tunisia, Egypt, Somalia, and so many others. The economic and human losses that follow these ecological disasters are better left unmentioned. The agricultural sector which is the mainstay of some countries in Africa has not been spared in this ecological onslaught. In many parts of Africa, farmers and pastoralists suffer poor yields as a result of flood and droughts and "climate change is likely to further reduce the length of growing season as well as force large regions of marginal agriculture out of production.

According to the Fourth Assessment Report of the IPCC, "Projected reductions in yield in some countries could be as much as $50 \%$ by 2020 , with small scale farmers being the most affected" (Boko, et al, 2007). This would adversely affect food security in the continent. Also, health cases and diseases have been on the increase as a result of devastating floods and droughts that displaced hundreds of thousands of people. Some of the common diseases include malaria, cholera, meningitis etc. While malaria is a burden to many African countries which is exacerbated by the consequences of climate change, "about 162 million people in Africa live in areas with a risk of meningitis (Molesworth et al, 2008). And among other factors, dryness, very low humidity and dusty conditions are climatic factors that could cause meningitis. These are obviously few out of an array of consequences of climate change in Africa.

\section{Impacts of Climate Change on African Traditional Religious Practices}

The impacts of climate change on African religious practices can be viewed from two stand points - direct impacts and Indirect Impacts. Directly, the change in the global climate and temperature has altered the usual patterns of rainfall, thereby affecting the practice of rain making in African traditional religion. While indirectly, it seems to have affected virtually everything that is of spiritual importance to the African. Ugwu and Ugwueye (2004:49) have observed that "the African world is suffused with religion. In other words, an African sees his world and interprets it in a religious perspective". Africans carry their religion into their daily routine activities farming, rearing of livestock, hunting, during illness and health, what they eat and drink etc, and whatever happens to them at anytime, and anywhere, is given a religious interpretation. This implies that the consequences of climate change in Africa like the decrease in yields, annihilation of some species of plants and animals, droughts, famine, floods and the attendant health issues like the spread of malaria, cholera and meningitis might have received religious interpretations. This is so, because in African traditional religious belief, misfortune and disasters do not arise without a cause - which can only be spiritually explained. However, for clarity and details, these impacts shall be further discussed below:

\subsection{Impact on Rain Making}

This is one of the essential elements in African traditional religious practices. The importance of rain for the survival of human, animal and plant has made "rain an important focus of religious practice in Africa (www.exploringafrica.matirx.msu.edu). Terje (2010) has observed that "in Tanzania, rain making has been an intrinsic part of culture and religion". Also, while the practice of rain making is practiced as an individual or group of individual's enterprises in some parts of Nigeria, especially among the Igbos of the Eastern Nigeria, it is a community practice in Zimbabwe. For instance, the Njele shrine located in the Matobo Hills of Matabeleland south province of Zimbabwe is usually visited annually between August and September when rainmakers from all over the country come together for the ritual purposes just before the rainy season (www.safarilodges.com). Indeed, the roles of rainmakers in African traditional society are nearly indispensable as they are "responsible for the wealth and health of their people by controlling and providing the life-giving waters-rainfall (Terje 2010). It should be however noted that this practice of rainmaking seems to be done with the aid of the knowledge of natural course of climatic seasons (i.e. rainy or dry seasons). By implication, if the natural course of climatic season is distorted as has been the case as a result of climate change, the precision of this practice will be greatly affected. Undoubtedly, rainfall has become erratic as the weather is becoming highly unpredictable as a result of 
the changes in the global climate and temperature. And this is a great challenge to the rainmakers as their initial knowledge of the operations of the weather is becoming obsolete and non-functional in the light of new climatic realities.

\subsection{Impact on Farming and Belief System}

The impact of climate change on farming and other agricultural activities in Africa is glaring. Due to inadequate and unpredictable rainfall, many farmers especially small scale farmers have suffered significant decrease in crop yields while some have lost out some planting seasons entirely. The situation can be linked to the case of Okonkwo in Achebe's (1958:18) Things Fall Apart, in which Okonkwo waited endlessly for rainfall after cultivating and planting his crops, but could not get a drop. This led to the loss of entire crops he planted as they died under the excruciating rays of the sun. Also, floods have devastatingly affected farmers in several countries in Africa. In Nigeria, for instance, the tale of "2012 flood" instills fear and sorrow as thousands of hectares of farmlands in over 20 states were submerged in water. Akpoborie (2012) recounts that;

From Cross River, Akwa Ibom, Rivers, Bayelsa, Delta, Anambra, Imo, through Edo to Niger, Benue, Taraba, Jigawa, Plateau and Kogi states come accounts of woe, death and destruction of homes, public buildings, roads, bridges, public utilities, crops, livestock and farms. Hundreds of thousands of hectares of farms have been swept away (about 400,000 hectares in Jigawa State alone).

This also, resulted in the premature harvesting of crops like yams, cassava crops etc as was the case in Cross River state where farmers resorted to harvesting their crops with Canoes. On the other hand, cases of droughts in some countries like Ethiopia, Kenya, Somalia etc has resulted in the death of crops and animals. All these put together have undoubtedly impacted on the religious beliefs and practices of the people. "The gods are angry" might be on the lips of traditional religious priests as the people would be praying to the spirits of their benevolent ancestors for a remedy from this array of misfortunes and ecological disasters. This is never to suggest that they are completely ignorant of the ecological changes; but that even the changes in the climate which has brought these misfortunes, did not occur without a cause. This 'cause' whether viewed religiously or scientifically, is largely man-made. Hence, perhaps, for the African traditionalists, a propitiatory sacrifice to the spirit of ancestors for forgiveness and remedy is not in the wrong direction. This is so, because it is firmly believed that "calamities such as epidemic, famine, drought, floods, serious illness etc are often incurred as a result of man's misdemeanors" (Awolabi, 1976:279).

\subsection{Impact of Soil fertility}

Climate change has impacted on the quality and fertility of soil through soil erosion caused by deforestation and indiscriminate tree harvest. This impact on the fertility of the soil has affected the belief system of the African traditional religious practitioners. Africans believe that divinities such as the earth goddess, (god of justice and fertility); Ufiajioku (who is the god of farm work among the Igbo of Eastern Nigeria) (Ugwu and Ugwueye 2004:41) and ancestral spirits provide for the fertility of crops and ensure bountiful harvests during harvesting seasons. So, any misfortune resulting in poor crop yields is often seen as a consequence of the breach of the harmonious relationship between the living and spirit being or gods; which often calls for a propitiatory sacrifice to the gods. Hence, these cases of poor agricultural yields that are currently experienced in African might have received religious interpretations as they affect the belief system of the people.

\subsection{Impact on Traditional Religious Festivals/Ceremonies}

Following the devastating impacts on farming and crop yields, one would expect that some ceremonies or festivals that celebrate bountiful farm harvests and other natural events might be affected as well. Hornby (2000:431) defines festival as "a day or period of the year when people stop working to celebrate a special event, often a religious one". And in the classification of festivals, Pilgrims (1978:65) gave four divisions; (i) festivals associated with ecological cycle (ii) festivals of non-ecological liturgical calendars (iii) festivals of the human cycle and (iv) occasional festivals.

Particularly, the first class involves festivals "whose timing, nature and intent are closely associated with the cycles of the natural universe, such as festivals that commemorate planetary movements and seasonal changes, planting, harvesting, hunting and fishing" (Ugwu and Ugwueye; 204:103). Festivals are acts of worship offered periodically to the supernatural, often to thank him for his blessings and benevolent acts in nature. But given the current realities of climate change and its attendant consequences, it becomes difficult to believe that these religious festivals and ceremonies were not or have not been affected in one way or the other.

Furthermore, there are other ways through which the traditional religion of the African might have been affected by climate change. For instance, the floods that swept through many communities especially in Nigeria, might have destroyed some traditional religious elements like shrines, statues and so on. Also, some displaced persons from different communities who are African traditional religious practitioners and who might have received aids from persons and Non-governmental Organizations (NGOs) owned by other religions like 
Christianity, Islam etc might have been converted into new faiths different from that of their fore-bearers. These among others, highlights the impacts of the phenomenon of climate change on African traditional religious practices.

\subsection{Impact on Traditional Music and Songs}

Music is an integral part of African traditional religion. In African traditional setting, music is not a mere production of sounds that are pleasurable to the ear, but a conscious explanation or expression of religio-cultural realities in rhythmic forms. These traditional religious songs and music often carry with them meanings and didactic lessons for the audience which "helps create and strengthen religious knowledge, corporate feeling and solidarity" (Mbiti 1969:67). Also, these songs and music often accompany different traditional activities, events or occasions such as yam festivals, burial ceremonies, coronations etc. However, some traditional musical instruments which are made from nature and which aid in the making of these traditional musics have unfortunately suffered the impact of climate change. For instance, the traditional drums which are made from special woods and animal skins; the flute which is also made from special woods etc have all had their materials in short supplies. Some of these special trees and animals that provide the raw materials for producing some of these traditional musical instruments have become scarce or absconded from forests (especially in the case of animals) as deforestation and desert encroachment continue. These have adversely affected traditional musical patterns and pleasurable intensity as some of these traditional musical instruments are either scarce or currently made with inferior or fake materials. This is as a result of the gradual extinction of species of plants and animals which are direct consequences of climate change.

\subsection{Impact on Traditional Medicine}

As noted in previous pages traditional medicine which is often administrated by traditional specialists or medicine men has a place in African traditional religion. These medicine men are believed to possess "extensive knowledge of the medical properties of herbs and roots." (Shorter 1973:137). With these properties such as special herbs and roots provided in nature, those traditional specialists play important roles in African communities, especially in the treatment of diseases, illness and during disease epidemic. However, this practice of medicine has not been spared by the phenomenon of climate change. Some of the special and rare plants, herbs and roots that are the major property with which these traditional specialists work, are gradually facing out as a result of the significant change in the earth climate. This has undoubtedly affected this practice of traditional medicine on the one hand while on the other hand, the evidence of increased diseases like malaria, meningitis etc. caused by the consequences of climate change has increased the medical challenges of traditional medicine, as there would be more diseases and patients to cure.

\section{Recommendations}

To mitigate these impacts of climate change on the traditional religious practices of Africans, the following are recommended:

- There should be a collective as well as community adjustment approach to the new realities of climate change. African traditional leaders should lead their respective affected communities to embrace and adjust to the changes in the global climate and resultant ecological realities. For instance, farmers should consistently observe the climatic seasons in order to adjust properly to the new planting and harvesting seasons.

- The African traditional religious practitioners should be made to understand the dangers of climate change as well as their roles in mitigating these dangers. Deforestations, bush burning, etc should be discouraged among rural dwellers as these practices contribute to climate change.

- The Government should also assist rural dwellers, especially farmers with sufficient agricultural incentives. Likewise, Loans should be made easily accessible to these farmers at a considerably little interest rate. This will boost the agricultural sector and food security in the country.

\section{Conclusion}

This paper has so far highlighted some elements in African traditional religious practice that have been adversely affected by the consequences of climate change. Indeed, this may not completely spring surprises as other religious systems and cultures like Christianity, Islam and the likes have in one way or the other felt the impact of climate change. It however, suggests that climate change is a global challenge with effects spread across board. Hence, all hands should be on deck in the global eco-sustainability campaign in order to achieve a sustainable environment.

\section{References}

Achebe, C (1958) Things Fall Apart. William Heinemann Ltd.

Akpoborie, T. (2012). Special Report: 2012: A Year of Raging Floods (www.westafricaninsight.org). Assessed on 
$10^{\text {th }}$ August, 2013.

Awolalu, J. O (1976) Sin and its Remissions in African Traditional Religion. Journal of the American Academy of Religion.

Baum, R (1999) Africana: The Encyclopedia of African and African American Experience. (www.exploringafrica.matrix.msu.edu). Assessed on $17^{\text {th }}$ August 2013.

Beyer, P (1998) Globalization and the Religion of Nature. In Oanne, P, Richard, H. R and Geoffrey, S (eds) Nature Religion Today: Paganism in the Modern World. Edinburgh: Edinburgh University Press.pp.1121.

Boko, M, I. Niang, A. Nyong, C. Vogel, A. Githeko, M. Medany et al (2007). Climate Change 2007; Impacts, Adaptation and Vulnerability. Contribution of Working Group II to the Fourth Assessment Report of the Intergovernmental Panel on Climate Change, M. L. Perry, O. F. Canziani, J. P Palutikof, P. J.Van Dar Linden and C. E. Hanson (Eds.). Cambridge University Press, Cambridge pp. 433-467.

Christensen, J. H, B Heitson, A. Busuioc, A. Chen, X. Gao, I. Held, et al (2007). Regional Climate Projections. Climate Changes 2007: The Physical Science Basics. Contribution of Working Group I to the Fourth Assessment Report of the Intergovernmental Panel on Climatic Change, S. Solomon, D. Qin, M. Manning, Z. Chen, M. Marquis, K. B. Averyt, M. Tignor et al (Eds.), Cambridge University Press, Cambridge. Pp. 847-940.

Ekwunife, A N. O (1990). Conservation in Igbo Traditional Religion. Enugu: SNAAP Press Ltd.

Ezechi, J.C (2011) The Dead Are Never Gone: Odo Masquerade and Contemporary Realities. Enugu: Monrovia Street New Haven.

Hornby, A. S (2000). Oxford Advance Learner's Dictionary, $6^{\text {th }}$ Edition. Great Clarendon Street, Oxford, Oxford University Press.

Indigenous African Religions (www.exploringafrica.matirx.msu.edu). Assessed on 17 ${ }^{\text {th }}$ August, 2013.

Mbiti, J.S (1969) African Religions and Philosophy. London: Heinemann.

Mclean, I and McMillan, A (2009) Oxford Dictionary of Politics. Oxford University Press, India.

Merriam-Webster Online Dictionary and Webster's New World College Dictionary, Fourth Edition.

Molesworth, A. M, L. E. Cuevas, S. J. Connor, A.P Morse and M.C. Thomson (2003). Environmental Risk and Meningitis Epidemics in Africa. Emerg. Infect. Dis. 9. Pp. 1287-1293.

Pilgrims, R. E (1976) "Rituals". In Introduction to the Study of Religion, T. M Hall (Ed.). New York: Harper.

Shorter, A (1973) African Religion and the Christian Church. London: Geoffrey Chapman Publishers.

Terje, O (2010) Rainmaking and Climate Change in Tanzania: Traditions, Rituals and Globalization (www.nai.uu.se). Assessed on $18^{\text {th }}$ August, 2013.

The Njele Shrine (Zimbabwe) Safari Lodges.com South Africa. (www.safarilodges.com) Assessed on august 18, 2013.

Ugwu, C.O.T and Uwueye, L. E. (2004). African Traditional Religion: A Prolegomenon. Lagos: Merit International Publications.

Umezurike, C (2012) The Implications of Climate Change for Democratic Governance in Nigeria. The Social Sciences. No.7 (Vol.3). pp.412-423.

World Water Forum (2000). The Africa Water Vision for 2005. Equitable and Sustainable Use of Water for Socio-Economic Development. UN Water/Africa. 
The IISTE is a pioneer in the Open-Access hosting service and academic event management. The aim of the firm is Accelerating Global Knowledge Sharing.

More information about the firm can be found on the homepage:

http://www.iiste.org

\section{CALL FOR JOURNAL PAPERS}

There are more than 30 peer-reviewed academic journals hosted under the hosting platform.

Prospective authors of journals can find the submission instruction on the following page: http://www.iiste.org/journals/ All the journals articles are available online to the readers all over the world without financial, legal, or technical barriers other than those inseparable from gaining access to the internet itself. Paper version of the journals is also available upon request of readers and authors.

\section{MORE RESOURCES}

Book publication information: http://www.iiste.org/book/

Academic conference: http://www.iiste.org/conference/upcoming-conferences-call-for-paper/

\section{IISTE Knowledge Sharing Partners}

EBSCO, Index Copernicus, Ulrich's Periodicals Directory, JournalTOCS, PKP Open Archives Harvester, Bielefeld Academic Search Engine, Elektronische Zeitschriftenbibliothek EZB, Open J-Gate, OCLC WorldCat, Universe Digtial Library, NewJour, Google Scholar

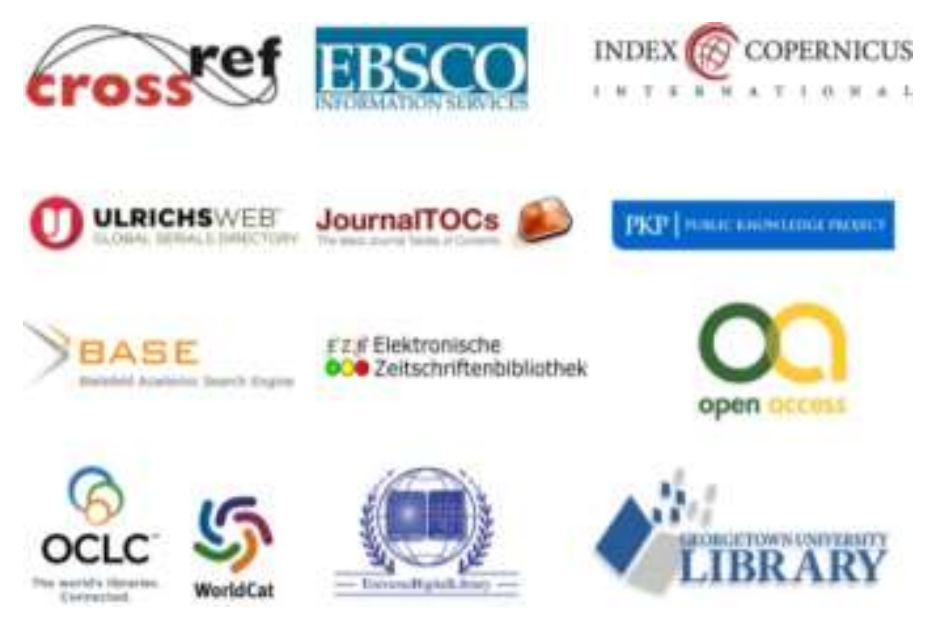

